\title{
INDOOR AIR QUALITY REQUIREMENTS FOR CIVIL BUILDINGS IN RUSSIAN REGULATIONS IN COMPARISON WITH INTERNATIONAL GREEN STANDARDS
}

\author{
Valery I. Telichenko ${ }^{1}$, Andrey A. Benuzh ${ }^{1,2}$, Nikita S. Rud \\ ${ }^{1}$ National Research Moscow State University of Civil Engineering, 26, Yaroslavskoye Shosse, Moscow, 129337. \\ ${ }^{2}$ Research Institute of Construction Physics of the Russian Academy of Architecture and Construction Sciences, \\ 21, Lokomotivny pr., Moscow, 127238.
}

\begin{abstract}
A new trend combining the concept of "green" buildings with the idea of preserving and strengthening peoples' health in order to eliminate sick building syndrome and building related illnesses has been observed worldwide. The COVID - 19 pandemic consequences outlined the necessity of updating the regulatory framework considering health preserving built environment principles in order to create sustainable and comfortable living environments. Indoor air quality directly correlates with human health: exposure to polluted air increases the risk of cardiovascular disease, myocardial ischemia, angina pectoris, hypertension and heart disease. It is known that indoor air quality depends not only on ambient air quality, but also on indoor sources of chemical and biological pollutants. Existing regulatory framework does not cover the civil buildings indoor sources of air pollution topic. This article discusses the terms of the Russian national technical and hygienic standards concerning the indoor air quality. A comparative analysis of the Russian Federation regulatory framework that refers the civil buildings indoor air quality with international "green" standards was carried out. Based on the analysis, the necessity to update the Russian regulatory framework is highlighted.
\end{abstract}

Keywords: sustainable development, environmental safety, regulatory framework, green standards, design criteria, comfort, health preserving.

\section{ТРЕБОВАНИЯ К КАЧЕСТВУ ВОЗДУХА ВНУТРЕННЕЙ СРЕДЫ ПОМЕЩЕНИЙ ГРАЖДАНСКИХ ЗДАНИЙ В РОССИЙСКИХ НОРМАХ В СРАВНЕНИИ С МЕЖДУНАРОДНЫМИ ЗЕЛЕНЫМИ СТАНДАРТАМИ}

\author{
В.И. Теличенко ${ }^{1}$, А.А. Бенуәж${ }^{1,2}$, Н.С. Рудь ${ }^{1}$ \\ ${ }^{1}$ Национальный исследовательский Московский государственный строительный университет (НИУ МГСУ), \\ 129337, г. Москва, Ярославское шоссе, д. 26. \\ ${ }^{2}$ ФГБУ «Научно-исследовательский институт строительной физики Российской академии архитектуры \\ и строительных наук» (НИИСФ РААСН), 127238, Москва, Локомотивный пр., д. 21.
}

\begin{abstract}
Аннотация: Сегодня во всем мире формируется новый тренд в строительстве, объединяющий концепцию «зеленого» строительства с идеей сохранения и укрепления здоровья людей, целью которого является борьба с «синдромом больного здания» и «болезней, связанных со зданием». Последствия пандемии COVID - 19 подчеркнули необходимость актуализации нормативно-технической базы с учетом принципов здоровьесбережения для создания устойчивой и комфортной среды жизнедеятельности человека. Качество воздуха внутренней среды зданий напрямую связано со здоровьем: воздействие на человека загрязненного воздуха увеличивает риск сердечно-сосудистых заболеваний, ишемии миокарда, стенокардии, гипертонии и заболеваний сердца. Фактически, известно, что помимо качества наружного воздуха, качество воздуха в помещении также зависит от наличия внутренних источников загрязнения, концентрации химических и биологических загрязнителей. Существующая нормативно - техническая база не охватывает тему внутренних источников загрязнения воздуха в гражданских зданиях.

В статье рассмотрены требования российских нормативно-технических и санитарно-эпидемиологических нормативных документов в отношении качества воздуха внутренней среды гражданских зданий. Проведен сравнительный
\end{abstract}


Indoor Air Quality Requirements for Civil Buildings in Russian Regulations in Comparison With International Green Standards

анализ отечественных нормативно-технических и санитарно-эпидемиологических нормативных документов с международными «зелеными» стандартами, на основании которого показана необходимость актуализации российской нормативно-технической базы с учётом международного опыта «зелёных» стандартов.

Ключевые слова: устойчивое развитие, экологическая безопасность, нормативно-техническая база, «зеленые» стандарты, критерии проектирования, комфорт, здоровьесбережение.

\section{INTRODUCTION}

Currently, the professional construction community information field worldwide is largely filled with the topic of creating a comfortable living environment. Within the framework of the renovation of the housing stock under the renovation program, as well as the federal projects "Housing" and "Ensuring a sustainable reduction of unsuitable housing stock" of the national project "Housing and the Urban Environment", the Government of the Russian Federation sets the task of creating a comfortable living environment. Analyzing the regulatory and technical base, research, scientific publications of leading experts in the field of design and construction, as well as feedback from users of buildings, it is noted that the setting of the task of creating a comfortable living environment and the methods of its implementation are interpreted in different ways by different specialists, which, often leads to unsatisfactory results. Thus, the design of space-planning and engineering solutions for a comfortable indoor environment of premises is currently difficult due to the lack of formed conceptual framework that reveals the meaning of the term "comfort" and the concept of "comfortable environment", as well as a criteria list that determines the indoor environment quality in the Russian Federation regulatory and technical framework.

Sick Building Syndrome and Green Buildings. According to the World Health Organization (hereinafter WHO), a person spends about $90 \%$ of the time indoors. Accordingly, the quality of life, health and well-being of a person directly depends on the quality of the internal environment of the buildings in which we spend a significant part of our life. The main factors forming the indoor environment quality (IEQ) are indoor air quality (IAQ); thermal comfort; water quality; visual comfort; acoustic comfort; spatial comfort (spaceplanning solutions); finishing materials. IEQ can negatively affect occupants' physical health (e.g., asthma exacerbation and respiratory allergies) through poor air quality, extreme temperatures, excess humidity, and insufficient ventilation and psychological health (e.g., depression and stress) through inadequate lighting, acoustics, and ergonomic design [1-4].

The term "sick building syndrome" (SBS) is used to describe situations in which building occupants experience acute health and comfort effects that appear to be linked to time spent in a building, but no specific illness or cause can be identified. The complaints may be localized in a particular room or zone or may be widespread throughout the building $[1,5,18]$. In contrast, the term "building related illness" (BRI) is used when symptoms of diagnosable illness are identified and can be attributed directly to airborne building contaminants $[3,5]$. Studies have shown that employees with such health conditions are absent more often, lose more work hours, and are less productive than employees without these conditions [6-8].

A new trend in construction is now formed worldwide, combining the concept of "green" buildings with the idea of preserving and strengthening people's health. Designing a new building, architects, and engineers strive to take into account not only environmental factors, reduced energy consumption, but also how built environment affects the health, wellbeing, mood, and performance of building users. To solve these 
problems, interdisciplinary teams are created, in which, in addition to architects, engineers, builders, designers, medical experts and psychologists are involved. Health-preserving approach is a great contributor to designing socially, economically and ecologically sustainable buildings.

The lockdown due to COVID-19 pandemic has outlined that sustainable and comfortable indoor environment is crucial for a person to maintain physical and psychological health during several months of "individual isolation". The consequences of the pandemic, and the imminent risk of its repetition, highlight the necessity to apply a new concept of health, in terms of indoor well-being, to housing policy and building sector [9]. Moreover, COVID-19 pandemic has showed the need to rethink approaches to the design of the human life environment and the need to implement tools for integrating the concept of "health preservation" into the existing design, construction and building operation paradigm.

British Research Establishment Environmental Assessment Methodology (BREEAM) 1990 and Leadership in Energy and Environmental Design (LEED) 1993 were established as constantly improving and dynamically developing systems of design, construction and building operation regulations to construct sustainable, comfortable, energy effective, high performance buildings. To regulate the design of health-saving (healthimproving) buildings' indoor environment, in 2014, the United States Green Building Council (USGBC) established the WELL Building Standard based on synergy of medical and engineering science. The Well Standard focuses its attention specifically on building users' health and wellbeing and consists of 115 design and building operation strategies criteria (59 design-referred criteria and 56 operation and management-referred criteria) divided in 10 concepts: air; water; nourishment; thermal comfort; sound; materials; mind; community; innovation. Compared to the widely used BREEAM and LEED building certification schemes the WELL Building Standard is the most precise and scrupulous in covering health and wellbeing topic [10].
In 2018, the Government of the Russian Federation approved the passport of the national project "Housing and Urban Environment", which includes four federal projects: Mortgage, Housing, Formation of a Comfortable Urban Environment, and Ensuring Sustainable Reduction of Unfit Housing. Within the framework of the indicated national project, the goal is to increase the volume of housing construction by 120 million square meters per year, with the following tasks:

- To update, by 2024, 279 units of existing regulatory and technical documents for the introduction of advanced technologies and the establishment of restrictions on the use of obsolete technologies in design and construction.

- Introduce, by 2024, 115 new regulatory and technical documents in construction to phase out the use of outdated technologies in design and construction.

Moreover, to accomplish the national project "Housing and Urban Environment" tasks, the Russian Government established the "Regulatory guillotine" in 2019. The "Regulatory Guillotine" is a tool for large-scale revision and cancellation of regulatory legal acts that negatively affect the overall regulatory environment.

By order of the Russian Federal Agency for Technical Regulation and Metrology dated September 15, 2016 №1315 Technical Committee for Standardization №366 "Green” technologies of the living environment and "green" innovative products" (TK 366) was created. TK 366 acts in order to form "green" standards for the advanced standardization of the promising technological base of the living environment and to ensure advanced technological development and accelerated implementation of scientific developments in production, conduct a full innovation cycle of research and development works, including the creation of samples of a "green" living environment [11]. TK 366 works on accomplishment of the national project "Housing and Urban Environment" tasks of developing new technical documents and updating existing technical regulatory framework. Today, the main TK 366 project is the development of Russian 
Indoor Air Quality Requirements for Civil Buildings in Russian Regulations in Comparison With International Green Standards

National "Green" Standards system as a free and accessible tool for implementing sustainability approaches in the Russian building sector. The Russian Federal Agency for Technical Regulation and Metrology approved the development of a GOST R standard "Assessment of built environment parameters' effects on human health" under the TK 366 by order dated March 18, 2020 №579, which is planned to be a regulatory tool of implementing health- preserving approaches in design, construction and building operation.

\section{Indoor Air Quality in Russian Regulatory Framework.}

In the Russian Federation, building sector regulatory framework is represented by both technical and hygienic standards. With regard to indoor air quality (IAQ) ventilation rates and air filtration requirements in different premises is regulated by "SP" while thresholds for particulate matters, volatile organic and volatile inorganic compounds is regulated by hygienic guidelines. In this article, a comparative analysis between Russian technical regulations, WELL and LEED concerning office building ventilation rates was conducted. SP 60.13330 .2016 regulates minimal ventilation rates for public buildings' premises. The LEED v4 and WELLv2 regulations concerning indoor air quality are based on ASHRAE 62.1-2010, which is why the analysis office building ventilation rates will be conducted using SP 60.13330.2016 and ASHRAE 62.1-2010. According to LEED v4, ventilation rates should match ASHRAE 62.1-2010. According to WELL v2, ventilation rates have to exceed ASHRAE 62.12010 by $60 \%$. The ASHRAE 62.1-2004 standard edition announces a new approach in determining the calculated air exchange for public buildings. The ventilation rate is calculated by summing up the need, taking into account the occupant density, to supply fresh outside air directly for the breathing of a person and for diluting pollutants emitted in the room where a person is located. Oddly enough, the air exchange rate per person for the most typical public buildings' premises has become lower than recommended in ASHRAE 62.1-1999 [12]. According to retrospective analysis, ventilation rates regulations in ASHRAE 62.1 - 2004/2010/2019 are identical for office premises as shown in table 1 below. In ASHRAE 62.1-1999 the air exchange rate in office premises was accepted as $10(1 / \mathrm{s})$ which is $36\left(\mathrm{~m}^{3} / \mathrm{h}\right.$ per person) with an area rate of $14\left(\mathrm{~m}^{2} /\right.$ person $)$ is:

$$
36 / 14=2.6\left(\mathrm{~m}^{3} / \mathrm{h} * \mathrm{~m}^{2} \text { of area }\right)
$$

In the ASHRAE 62.1 - 2004/2010/2019 versions exchange rate in office premises is $2,5(1 / \mathrm{s}$ per person) which is $9\left(\mathrm{~m}^{3} / \mathrm{h}\right)$, adding $0,3\left(1 / \mathrm{s} \mathrm{per}^{2}\right.$ of area) or $1.08\left(\mathrm{~m}^{3} / \mathrm{h}\right.$ per $\mathrm{m}^{2}$ of area $)$, which at the same rate of $14 \mathrm{~m}^{2} /$ person is:

$$
\begin{gathered}
(9+1.08 * 14)=24\left(\mathrm{~m}^{3} / \mathrm{h} \text { per person }\right) \\
24 / 14=1.7\left(\mathrm{~m}^{3} / \mathrm{h}^{*} \mathrm{~m}^{2} \text { of area }\right)
\end{gathered}
$$

Air exchange rate for office premises in ASHRAE 62.1 - 1999 compared to ASHRAE 62.1 -

\begin{tabular}{|c|c|c|c|c|}
\hline $\begin{array}{l}\text { Premise } \\
\text { name }\end{array}$ & $\begin{array}{c}\text { Ventilation rate } \\
\text { ASHRAE 62.1-1999 } \\
\text { m³/(pers*hour })^{3}\end{array}$ & $\begin{array}{c}\text { Ventilation rate } \\
\text { ASHRAE 62.1-2004 } \\
\text { m³/(pers*hour) }\end{array}$ & $\begin{array}{c}\text { Ventilation rate } \\
\text { ASHRAE 62.1-2010 } \\
\text { m³/(pers*hour) }\end{array}$ & $\begin{array}{c}\text { Ventilation rate } \\
\text { ASHRAE 62.1-2019 } \\
\text { m³ }^{3} /(\text { pers*hour) }\end{array}$ \\
\hline Office & 36 & 24 & 24 & 24 \\
\hline Breakrooms & 30 & 12 & 12 & 12 \\
\hline
\end{tabular}
$2004 / 2010 / 2019$ versions is 1,5 times less.

Table 1. ASHRAE ventilation rates regulations retrospective analysis. 
The trend towards a decrease [13] in the calculated air exchange for most public buildings, which reveals the resource and energy efficiency approach in ASHRAE and LEED standards, is obvious. Considering this background, the air exchange rates in SP 60.13330.2016 are overestimated for office premises. The ventilation rate for office premises in $\mathrm{SP}\left(60 \mathrm{~m}^{3} / \mathrm{h}\right.$ per person) exceeds ASHRAE 62.1-2010/LEED v4 (24 m $/ \mathrm{h}$ per person) 2,5 times, which doesn't correspond to the energy efficiency approach. On the contrary, taking into account the building users' health and wellbeing approach, the SP
60.13330 .2016 ventilation rate requirement $\left(60 \mathrm{~m}^{3} / \mathrm{h}\right.$ per person) exceeds WELL v2 (39 $\mathrm{m}^{3} / \mathrm{h}$ per person) by 1,5 times, which perfectly fits the health- preserving principles (Table 2). However, due to improper distribution of such large volumes of air in office premises workers may feel uncomfortable because of drafts [12]. Often, implementation of green practices results in poor IAQ: energy efficiency strategies that increase indoor pollutants, location of buildings near transportation emissions, and the use of natural ventilation in areas with elevated outdoor pollution [14].

Table 2. Ventilation rates regulations comparison.

\begin{tabular}{|c|c|c|c|}
\hline Premise name & $\begin{array}{c}\text { Ventilation rate } \\
\text { SP60.13330.2016 } \\
\mathbf{m}^{3} / \text { (pers*hour) }\end{array}$ & $\begin{array}{c}\text { Ventilation rate } \\
\text { WELL v2 } \\
\mathbf{m}^{3} /(\text { pers*hour) }\end{array}$ & $\begin{array}{c}\text { Норма воздухообмена по } \\
\text { ASHRAE 62.1-2010 } \\
\text { (LEED v4) } \\
\mathbf{m}^{\mathbf{3}} / \text { (pers*hour) }\end{array}$ \\
\hline Office & 60 & 39 & 24 \\
\hline Breakrooms & 60 & 19 & 12 \\
\hline
\end{tabular}

According to "Regulatory guillotine" mechanism approved by the Government of the Russian Federation, 108 hygienic standards were decided to be revised, in order to introduce the unified hygienic standard "Hygienic standards of environmental factors" (HS 1.2-20) on 01.01.2021. In particular the hygienic standard "Threshold limit value (TLV) of pollutants in ambient air of urban areas" (HS 2.1.6.3492-17), which regulates threshold limit values (TLV) of particulate matters, volatile organic compounds (VOCs), semi-volatile organic compounds (SVOCs) and volatile organic compounds (VOC) is revised. Ambient air quality and indoor air quality are in direct correlation $[14,15]$. The migration of dust and toxic substances contained in the atmosphere is due to the aerodynamics of the airflows movement. When ventilating buildings by natural or mechanical ventilation, hazardous contaminants of ambient air enter the premises. Therefore, TLVs of pollutants in ambient air is crucial for IAQ. It is necessary to note that among others the hygienic standard "Threshold limit value (TLV) of pollutants in working zone air" HS 2.2.5.353218 is revised due to the "Regulatory guillotine". However, HS 2.2.5.3532-18 regulates IAQ of industrial buildings and cannot be implemented for civil ones, as sources of exposure for these building types are different. Long - term exposure to VOCs cause acute symptoms such as nose, throat, and eyes irritations, headaches, allergic skin reactions, nausea, dizziness. Moreover, several VOCs and SVOCs may not be immediate hazards but can lead to chronic health risks such as liver and kidney damage, the development of cancerous tumors, hematopoietic organs and the central nervous system damage, vascular atherosclerotic changes, chromosomal aberrations [16-21]. 
Indoor Air Quality Requirements for Civil Buildings in Russian Regulations in Comparison With International Green Standards

Table 3. Improved and worsened TLVs of airborne contaminants.

\begin{tabular}{|c|c|c|c|c|}
\hline \multirow{2}{*}{ Compounds } & \multicolumn{2}{|c|}{ HS 2.1.6.3492-17 $\left(\mathrm{mg} / \mathrm{m}^{3}\right)$} & \multicolumn{2}{|c|}{ HS1.2-20 $\left(\mathrm{mg} / \mathrm{m}^{3}\right)$} \\
\hline & TLVom & TLVda & TLVom & TLVda \\
\hline Benzene & 0,3 & 0,1 & 0,3 & 0,06 \\
\hline 1,3-Butadiene & 3 & 1 & 3 & 0,02 \\
\hline Hexachloroethane & 0,05 & - & - & 0,05 \\
\hline Tetrachloromethane & 4 & 0,07 & 4 & 0,04 \\
\hline 1-Phenylethanone & 0,01 & - & 0,003 & - \\
\hline Butylethylene & 0,4 & 0,985 & 0,4 & 0,085 \\
\hline 1-Hydroxy-4-chlorobenzene & 0,0015 & 0,003 & 0,015 & 0,003 \\
\hline $\begin{array}{c}\begin{array}{c}\text { Dimethylbenzene-1,2- } \\
\text { dicarbonate }\end{array} \\
\end{array}$ & 0,03 & 0,007 & 0,03 & 0,01 \\
\hline Potassium chloride & 0,03 & 0,01 & 0,3 & 0,1 \\
\hline Ozone & 0,16 & 0,03 & 0,16 & 0,1 \\
\hline Acrolein & 0,03 & 0,01 & 0,1 & 0,04 \\
\hline Allyl acetate & 0,4 & - & 0,04 & - \\
\hline Propyl pentanoate & 0,003 & - & 0,03 & - \\
\hline Mercury & - & 0,0003 & 0,0006 & 0,0004 \\
\hline Selenium dioxide & 0,1 & 0,05 & 0,25 & - \\
\hline $\begin{array}{c}\text { Odorant mixture of natural } \\
\text { mercaptans with a mass content } \\
\text { of ethanethiol } 26-41 \% \text {, } \\
\text { isopropane-thiol } 38-47 \% \text {, sec- } \\
\text { butanethiol } 7-13 \% \\
\end{array}$ & 0,00005 & - & 0,012 & - \\
\hline Tripropylamine & 0,4 & 0,02 & - & 0,25 \\
\hline Chloroform & 0,1 & 0,03 & 0,15 & 0,03 \\
\hline Trichlorofluoromethane & 100 & 1 & 100 & 10 \\
\hline 1,1,1-trichloroethane & 2 & 0,2 & 2 & 1 \\
\hline Carbon monoxide & 5 & $\begin{array}{c}3 \\
(8 \mathrm{~h}) \\
\end{array}$ & 23 & $\begin{array}{c}10 \\
(8 \mathrm{~h}) \\
\end{array}$ \\
\hline Hydrofluoride & 0,02 & 0,005 & 0,02 & 0,014 \\
\hline Chloroprene & 0,02 & 0,002 & 0,02 & 0,007 \\
\hline Chloroethane & - & 0,2 & 30 & - \\
\hline Vinyl chloride & - & 0,01 & 0,18 & 0,04 \\
\hline
\end{tabular}

Comparative analysis of hygienic standard HS 1.2-20 addenda 1 "Ambient air of urban areas" and HS 2.1.6.3492-17 was conducted, the results are shown in table 3 . TLVs for 15 compounds were introduced. Out of 658 compounds, TLVs were increased for 19 compounds and decreased for 6. TLVs of 618 compounds remained unchanged compared to HS 2.1.6.3492-17. For 62 compounds, average annual TLV (TLVaa) was established based on the 
additional probability of developing malignant neoplasms (cancer) in an individual throughout his life (an individual carcinogenic risk at the level of $1 \times 10^{-4}$, corresponding to 1 additional case of cancer per 10 thousand population). Daily average TLV (TLVda) of benzene was decreased from 0,1 to $0,06 \mathrm{mg} / \mathrm{m}^{3}$, which corresponds to the LEED v4 threshold. TLVda of tetrachloromethane was decreased from 0,07 to $0,04 \mathrm{mg} / \mathrm{m}^{3}$, which corresponds to the LEED v4 threshold, comparative analysis between HS 2.1.6.3492-17, WELL v2 and LEED v4 was conducted in previous researches [21]. TLVda of trichlorofluoromethane was increased from 1 to $10 \mathrm{mg} / \mathrm{m}^{3}$. TLV da of trichlorofluoromethane was increased from 0,2 to $1 \mathrm{mg} / \mathrm{m}^{3}$, however the study [22] showed that $0,02 \mathrm{mg} / \mathrm{m}^{3}$ is the most stringent requirement compared to WELL and LEED. TLVs of carbon monoxide were dramatically increased. One time maximum TLV (TLVom) was increased from 5 to $23 \mathrm{mg} / \mathrm{m}^{3}$. TLVda ( 8 hour exposure) of carbon monoxide was increased from 3 to $10 \mathrm{mg} / \mathrm{m}^{3}$.

Hygienic standard HS 1.2-20 are developed in coherence with federal law № 52-FL "On the sanitary and epidemiological wellbeing of the population" dated March 30, 1999. According to Article 38, Clause 2, the development of sanitary rules should provide for conducting comprehensive research, determining sanitary and epidemiological requirements, calculating and assessing risk to human health, establishing safety criteria, analyzing international experience, establishing grounds for revision of hygienic and other standards, forecasting the social and economic consequences of the application of sanitary rules. However, in hygienic standard HS 1.2-20 project no research results justifying changes have been released.

The analyzed hygienic standard regulate "ambient air," the term has been interpreted as "outdoor air," or air external to buildings, excluding indoor air. While outdoor air quality can affect the indoors, and indoor air contains pollutants from both outdoor and indoor origin [14]. The indoor air pollutant sources are construction work, furniture, textile, clothes, carpeting, and wood processing household appliances, particle board, painting, plywood. Existing regulatory framework does not cover the indoor air pollutants topic although concentration of chemical and biological pollutants is a crucial IAQ indicator.

Another key indicator of air quality is the concentration of particulate matter PM10 inhalable particles, with diameters that are generally 10 microns and smaller, and PM2.5 - fine inhalable particles, with diameters that are generally 2.5 microns and smaller. Ammonia, organic and elemental carbon, sulfates, nitrates, chloride ions, sodium, potassium, zinc, calcium, iron, magnesium and copper ions, crustal minerals, particle-bound water, polycyclic aromatic hydrocarbons are the most common chemical components of PM10 and PM2,5. These components are absorbed by alveolar macrophages (as it is one of the main lung functions), which causes inflammation of lung tissue, resulting in chronic hypoxemia. Besides, chronic exposure to PM 2.5 causes the DNA damage itself and influence the DNA repair [23]. Overall, these processes lead to cancerogeneses, which results in increased lung cancer mortality $[24,25]$. According to the 2013 WHO report "Health Exposure to Particulate Matter" PM2.5 accounts for approximately $3 \%$ of deaths from cardiopulmonary pathology and $5 \%$ of deaths from lung cancer. The research [26] found that every $0.01 \mathrm{mg} / \mathrm{m} 3$ increase of PM10 stands for respiratory mortality increase by $0.58 \%$. Table 4 shows the result of a comparative analysis of the TLVda of particulate matter in HG 2.1.6.3492-03; HS 2.1.6.3492-17; WELL standard; LEED standard and maximum permissible threshold value recommended by WHO for the concentration of suspended particles PM10; PM2.5. The values of the required TLVs are reduced to a single dimension $-\mathrm{mg} / \mathrm{m}^{3}$. 
Indoor Air Quality Requirements for Civil Buildings in Russian Regulations in Comparison With International Green Standards

Table 4. Comparison of TLVs of particulate matters PM10, PM2,5.

\begin{tabular}{|c|c|c|}
\hline Particulate Matter Thresholds & PM10 & PM2.5 \\
\hline TLVda in HS 2.1.6.3492-03 $\left(\mathbf{m g} / \mathbf{m}^{3}\right)$ & Not regulated & Not regulated \\
\hline TLVda in HS 2.1.6.3492-17 $\left(\mathbf{m g} / \mathbf{m}^{3}\right)$ & 0,06 & 0,035 \\
\hline TLVda in HS1.2-20 $\left(\mathbf{m g} / \mathbf{m}^{3}\right)$ & 0,06 & 0,035 \\
\hline WELLv.2 $\left(\mathbf{m g} / \mathbf{m}^{3}\right)$ & 0,02 & 0,01 \\
\hline TLVda in WHO guidelines $\left(\mathbf{m g} / \mathbf{m}^{3}\right)$ & 0,05 & 0,025 \\
\hline
\end{tabular}

The most stringent requirements for the particulate matter thresholds PM10; PM2.5 are imposed by the WELL Building Standard. TLV regulated by HS1.2-20 PM10 particles is 3 times higher than the WELL requirements, and PM2.5 particles are 3.5 times higher.

\section{CONCLUSIONS}

1. Ambient air quality directly affects indoor air quality. However, indoor air contains both external and internal pollutants and is not dependent only on outdoor air. Emissions from furniture, finishing materials, household chemicals and their impact on the state of the indoor air quality of civil buildings' premises and are currently not standardized by either technical or sanitary - epidemiological regulations in the Russian Federation. The hygiene standards do not consider the indoor air quality of civil buildings as a separate category.

2. Research results justifying changes in threshold limit values of several VOCs and SVOCS have not been released. Threshold limit values of several VOCs and SVOCS should be reconsidered within a view to international "green" standards WELL and LEED. Based on article 38, clause 2 of Federal Law № 52 the development of sanitary rules should provide for conducting comprehensive research, determining sanitary and epidemiological requirements, calculating and assessing risk to human health, establishing safety criteria, analyzing international experience. 3. It is crucial to create interdisciplinary teams consisting of researchers and practitioners, experts of various fields: architects, structural engineers, engineers, builders, medical professionals and psychologists in order to solve the problems of maintaining and improving the health and wellbeing of building users. Interdisciplinary teams should not only be involved in design but also take part in developing building sector regulatory framework.

4. It is important to consider a little shared vocabulary between disciplines and absence of interdisciplinary building sector regulatory documents aimed at regulating design, construction and operation of buildings in accordance with sustainable and health preserving principles, since buildings and are multi-dimensional systems influenced by trends and processes operating at local, national and global levels. Since the building sector regulatory framework in Russia is represented by both technical and hygienic standards, in order to create an accessible tool to design and build comfortable living environments, the Technical Committee for Standardization №366 "Green" technologies of the living environment and "green" innovative products" should work on development of interdisciplinary standards based on health preserving built environment principles.

\section{REFERENCES}

1. Singh, A., Syal, M., Grady, S. C., \& Korkmaz, S. Effects of Green Buildings on Employee Health and Productivity.//American 
Journal of Public Health, 2010 100(9), 1665 1668. doi:10.2105/ajph.2009.180687

2. Schleiff PL, Park J, Kreiss K. Buildingrelated re-spiratory disease in college employees. // Am J Respir Crit Care Med. 2003;167(7):A503

3. Skov P., Valbjørn O., Pedersen B.V. Influence of indoor climate on the sick building syndrome in an office environment. // The Danish Indoor Climate Study Group. Scand J Work Environ Health. 1990;16(5):363-371

4. Spengler J.D., Sexton K. Indoor air pollution: a public health perspective. // Science. 1983;221(4605): 9-17.

5. United States Environmental Protection Agency (EPA). Indoor Air Facts No. 4 (Revised). Sick Building Syndrome. Air and Radiation; United States Environmental Protection Agency: Washington, DC, USA, 1991.

6. Fisk W.J. Health and productivity gains from better indoor environments and their relationship with building energy efficiency. // Annu Rev Energy Environ. 2000;25: 537566.

7. Heschong L. Windows and Offices: A Study of Office Worker Performance and the Indoor Environment. // Fair Oaks, CA: HeschongMahone Group; 2003. http://www.lrc.rpi.edu/ programs/daylighting/pdf/Daylight Benefits. pdf.

8. Wargocki P., Wyon D.P., Fanger P.O. Productivity is affected by the air quality in offices. // Proc Healthy Buildings. 2000;1:635640. Available at: http://www. senseair.se/ Articles/A8_237.pdf.

9. D'Alessandro D., Gola M., Appolloni L., Dettori M., Fara G.M., Rebecchi A., Settimo G., Capolongo S. COVID-19 and Living space challenge. Well-being and Public Health recommendations for a healthy, safe, and sustainable housing. // Acta Bio Med [Internet]. 2020Jul.20 [cited 2020Dec.21];91(9-S):61-5. DOI: 10.23750/ abm.v91i9-S.10115 Available from: https:// www.mattioli1885journals.com/index.php/ actabiomedica/article/view/10115
10. Potrč Obrecht, T., Kunič, R., Jordan, S., \& Dovjak, M. Comparison of Health and Well-Being Aspects in Building Certification Schemes. // Sustainability, 2019, 11(9), 2616. doi:10.3390/su11092616

11. Telichenko V.I., Slesarev M.Yu. "Zelenaya" standartizatsiya tekhnologiy formirovaniya prirodopodobnoy sredy zhiznedeyatel'nosti ["Green" standardization of technologies for forming the nature-friendly living environment]. // Vestnik MGSU [Proceedings of the Moscow State University of Civil Engineering]. 2018, vol. 13, issue 5 (116), pp. 558-567. DOI: www.dx.doi. org/10.22227/1997-0935.2018.5.558-567

12. V.I. Livchak. Air exchange rates of public buildings and the consequences of their overestimation. // AVOK, 2007, no. 6. https:// www.abok.ru/for_spec/articles.php?nid=3711

13. Muller, Chris \& Chamas, Hassan \& Member, Zouggari. ASHRAE Standard 62.1 and LEED: Using Enhanced Air Cleaning to Integrate IAQ and Energy Conservation. 2017

14. Steinemann A., Wargocki P., Rismanchi B. Ten questions concerning green buildings and indoor air quality. // Building and Environment (2016), 112, 351-358. doi:10.1016/j. buildenv.2016.11.010

15. Volkova N.G., Tseshkovskaya E.Y. Ecological aspects of the microclimate in residential and public buildings. // Biospheric compatibility: human, region, technologies. 2019. №4, pp. 63-73. (In Russian).

16. Soni, V., Singh, P., Shree, V., \& Goel, V. Effects of VOCs on Human Health. / Air Pollution and Control, 2017,119142. doi:10.1007/978-981-10-7185-0_8

17. Filley CM, Halliday W, KleinschmidtDemasters BK. The effects of toluene on the central nervous system. J Neuropathol Exp Neurol. 2004;63(1): $1-12$.

18. Samet J. Environmental controls and lung disease. // Am Rev Respir Dis, 1990, 142:915939

19. Jia C., Batterman S., Godwin C. (2008) VOCs in industrial, urban and suburban 
Indoor Air Quality Requirements for Civil Buildings in Russian Regulations in Comparison With International Green Standards

neighborhoods, Part 1: indoor and outdoor concentrations, variation, and risk drivers. // Atmos Environ 42:2083-2100

20. IPCS (1993) Benzene. Geneva, World Health Organization, International Programme on Chemical Safety, Environmental Health Criteria.

21. Agency for Toxic Substances and Disease Registry (ATSDR) (1999) Toxicological Profile for Ethylbenzene (Update). Public Health Service, U.S. Department of Health and Human Services, Atlanta, GA

22. Telichenko V.I., Benuzh A.A., Rud N.S., Yeye O.W. Design Parameters of a Comfortable Living Environment in the Normative Documentation. // Promyshlennoe i grazhdanskoe stroitel'stvo [Industrial and Civil Engineering], 2020, no. 5, pp. 51-56. (In Russian). DOI: 10.33622/08697019.2020.05.51-56.
23. Xing Y.F., Xu Y.H., Shi M.H., Lian Y.X. The impact of PM2.5 on the human respiratory system. // J Thorac Dis 2016;8(1):E69-E74. doi: 10.3978/j.issn.2072-1439.2016.01.19

24. Schwartz J. Harvesting and long term exposure effects in the relation between air pollution and mortality. // Am J Epidemiol 2000;151:440-8. doi: 10.1093/oxfordjournals. aje.a010228.

25. Franklin M., Koutrakis P., Schwartz P. The role of particle composition on the association between PM2.5 and mortality. // Epidemiology 2008;19:680-9. doi: 10.1097/ ede.0b013e3181812bb7.

26. Analitis A., Katsouyanni K., Dimakopoulou

K. Short-term effects of ambient particles on cardiovascular and respiratory mortality. Epidemiology 2006;17:230-3. doi: 10.1097/01.ede.0000199439.57655.6b.
Valery I. Telichenko. Honorary president of National Research Moscow State University of Civil Engineering, Professor, Doctor of Technical Sciences, Academician of RAASN, Tel .: +7 (499) 678-28-83 ext. 2482. E-mail: president@mgsu.ru

Andrey A. Benuzh. Associate Professor of the Department of Design of Buildings and Structures, junior research associate of the department promising priority areas in construction science NIISF RAASN, Candidate of Science (Engineering).Тел.: +7 (925) 057-34-37. E-mail: BenuzhAA@mgsu.ru

Nikita S. Rud. PhD student, National Research Moscow State University of Civil Engineering, Department of Construction of Thermal and Nuclear Power Facilities of MGSU, Tel.: +7 (965) 346-01-46 E-mail: rud.nikita96@mail.ru
Теличенко Валерий Иванович. Почетный президент Национального исследовательского Московского государственного строительного университета, профессор, докт. техн.наук, академик РААСН. Тел.: +7 (499) 678-28-83 вн. 2482. E-mail: president@mgsu.ru

Бенуж Андрей Александрович. Доцент кафедры проектирования зданий и сооружений Национального исследовательского Московского государственного строительного университета, младший научный сотрудник отдела перспективные приоритетные направления в строительной науке НИИСФ РААСН, доцент, кандидат технических наук. Тел.: +7 (925) 057-34-37. E-mail: BenuzhAA@mgsu.ru

Рудь Никита Сергеевич. Аспирант кафедры строительства объектов тепловой и атомной энергетики, Тел.: +7 (965) 346-01-46, E-mail: rud.nikita96@mail.ru 